\title{
Analisis Penggunaan E-SPT PPn Terhadap Kepatuhan Pelaporan SPT Oleh Wajib Pajak Pada Kantor Pelayanan Pajak Pratama llir Timur
}

\author{
Afriza Hardianti ${ }^{1}$, Totok Sudiyanto ${ }^{2}$, Andri Eko Putra ${ }^{3}$ \\ ${ }^{1}$ Fakultas Ekonomi dan Bisnis Universitas PGRI Palembang, antiafriza@gmail.com \\ ${ }^{2}$ Fakultas Ekonomi dan Bisnis Universitas PGRI Palembang, totoktajir1978@gmail.com \\ ${ }^{3}$ Fakultas Ekonomi dan Bisnis Universitas PGRI Palembang, andri ekoputra@yahoo.com
}

\begin{abstract}
ABSTRAK
Penyampaian SPT manual dinilai masih mempunyai kekurangan terutama bagi Wajib Pajak yang melakukan transaksi cukup besar harus melampirkan dokumen yang jumlahnya pun cukup besar kepada Kantor Pelayanan Pajak yang menyebabkan pelaporan SPT menjadi tertunda dan terlambat karena proses perekaman data memakan waktu cukup lama. Dengan adanya penggunaan E-SPT proses kerja dan layanan perpajakan dapat bekerja dengan baik, lancar, akurat, dan lebih mudah bagi pembayar pajak atas kewajiban pajak mereka, Maka dengan diterapkannya sistem online tersebut dalam perpajakan diharapkan dapat meningkatkan kepatuhan Wajib Pajak untuk melakukan pelaporan pajak. Penelitian ini bertujuan untuk menganalisis Penggunaan E-SPT PPN Terhadap Kepatuhan Pelaporan SPT Oleh Wajib Pajak Pada Kantor Pelayanan Pajak Pratama llir Timur. Metode yang digunakan dalam penelitian ini adalah metode kualitatif. Hasil ini menunjukkan bahwa Tingkat Kepatuhan Wajib Pajak Orang Pribadi yang melaporkan E-SPT Masa PPN pada tahun 2017 sampai 2019 pada KPP Pratama llir Timur selalu mengalami Penurunan. Dengan kategori Cukup Patuh terjadi pada Tahun 2017dengan persentase 76,05\%-86,77\% dan dengan kategori Kurang Patuh terjadi pada Tahun 2018 dan 2019 dengan persentase 64,35\%-76,85\%. Kesimpulan dari penelitian Analisis Penggunaan E-SPT PPN Terhadap Kepatuhan Pelaporan SPT Oleh Wajib Pajak pada KPP Pratama llir Timur adalah Kurang Patuh dengan Persentase rata-rata 75,87\%.
\end{abstract}

Kata Kunci : Pajak, E-SPT PPN, Tingkat Kepatuhan Wajib Pajak

\section{ABSTRACT}

Submission of manual tax return is considered to still have shortcomings, especially for taxpayers who conduct large enough transactions must attach documents that are quite large in number to the Tax Office which causes the reporting of tax returns to be delayed and delayed because the data recording process takes a long time. With the use of E-SPT taxation work processes and services can work well, slowly, accurately, and more easily for taxpayers for their tax obligations, then the implementation of the online system in taxation is expected to improve taxpayer compliance for tax reporting. This study aims to analyze the use of E-SPT PPN Against Taxpayer Reporting Compliance by Taxpayers at the Ilir Timur Pratama Tax Office. The method used in this study is a qualitative method. These results indicate that the Compliance Level of Personal Taxpayers who report the Period E-SPT PPN in 2017 to 2019 at the East llir KPP always decreases. With the category Adequately Compliant occurred in 2017 with a percentage of $76.05 \%-86.77 \%$ and with the category of Non-Compliance occurred in 2018 and 2019 with a percentage of $64.35 \%-76.85 \%$. So it can be concluded the results of the study Analysis of the Use of E-SPT PPN Against Taxpayer Reporting Compliance by Taxpayers at East llir $K P P$ is Less Compliant with an average percentage of $75.87 \%$.

Keywords: Taxes, E-SPT PPN, Taxpayer Compliance Level

\section{A. PENDAhULUAN}

Indonesia adalah negara berkembang pada saat ini, untuk meningkatkan status berkembang tersebut menjadi negara maju maka negara Indonesia harus berubah menjadi lebih baik lagi. Dimana Indonesia harus memiliki infrastruktur yang kuat dan kokoh, sarana prasarana bagi masyarakat Indonesia yang memadai, tingkat pendidikan yang tinggi guna menghasilkan calon penerus bangsa yang ahli di 
bidangnya, tingkat kesehatan yang tinggi sehingga kesejahteraan masyarakat yang di inginkan akan tercapai. Jika kita ingin hal tersebut dapat tercapai maka negara Indonesia harus memiliki pendapatan negara yang tinggi untuk dapat membangun negara maju seperti yang di inginkan selama ini.Saat ini pendapatan tertinggi dan utama bagi negara Indonesia masih berasal dari sektor pajak.

Sebagai penerimaan utama bagi negara pajak bertujuan meningkatkan kesejahteraan rakyat melalui perbaikan dan peningkatan sarana prasarana publik serta sumber dana bagi pemerintah untuk membiayai infrastruktur yang dibutuhkan oleh pemerintah. Pemerintah telah melakukan berbagai upaya dalam bidang perpajakan melalui penyempurnaan atas pelaksanakan sistem perpajakan salah satunya yaitu dengan adanya ketentuan Direktorat Jendral Pajak sebagai lembaga negara yang membidangi urusan segala perpajakan yang dapat membuat kebijakan yang dapat meningkatkan pemasukan pajak bagi negara, dan salah satu kebijakan terbaru dari Direktorat Jenderal Pajak adalah menerapkan sistem elektronik (E-SPT), salah satu contoh Surat Pemberitahuan elektronik ( E-SPT) tersebut yaitu E-SPT PPN Masa dalam pelaporan pajak. Dalam Surat Edaran Direktorat Jenderal Pajak Nomor: SE-03/PJ/2019, yang berisi. Tentang Teknis Tata Cara Penyampaian, Penerimaan, dan Pengolahan Surat Pemberitahuan dalam Bentuk Elektronik dijelaskan dalam Pasal 2 no 1 bahwa "Wajib Pajak wajib menyampaikan SPT dalam bentuk elektronik (E-SPT)". Berikut adalah laporan wajip pajak lapor SPT PPN Masa di KPP Prtama Palembang Ilir Timur.

\section{Tabel Laporan Wajib Pajak Lapor SPT PPn Masa di KPP Prtama Palembang Ilir Timur Periode 2017-2019}

\begin{tabular}{|c|c|c|c|c|}
\hline TAHUN & BULAN & $\begin{array}{c}\text { JUMLAH } \\
\text { SPT MASA } \\
\text { PPN }\end{array}$ & $\begin{array}{c}\text { JUMLAH } \\
\text { TEPAT WAKTU } \\
\text { LAPOR SPT }\end{array}$ & $\begin{array}{c}\text { JUMLAH } \\
\text { TELAT } \\
\text { LAPOR SPT }\end{array}$ \\
\hline \multirow{12}{*}{2017} & 1 & 2.925 & 2.414 & 111 \\
\hline & 2 & 2.922 & 2.471 & 171 \\
\hline & 3 & 2.973 & 2.403 & 142 \\
\hline & 4 & 2.952 & 2.401 & 132 \\
\hline & 5 & 2.952 & 2.414 & 109 \\
\hline & 6 & 2.953 & 2.515 & 113 \\
\hline & 7 & 2.996 & 2.441 & 125 \\
\hline & 8 & 2.986 & 2.461 & 134 \\
\hline & 9 & 2.983 & 2.566 & 129 \\
\hline & 10 & 2.980 & 2.677 & 150 \\
\hline & 11 & 2.994 & 2.689 & 91 \\
\hline & 12 & 3.030 & 2.614 & 80 \\
\hline \multirow{11}{*}{2018} & 1 & 3.019 & 2.514 & 365 \\
\hline & 2 & 2.961 & 2.390 & 308 \\
\hline & 3 & 2.955 & 2.345 & 443 \\
\hline & 4 & 2.993 & 2.451 & 331 \\
\hline & 5 & 3.107 & 2.519 & 360 \\
\hline & 6 & 3.011 & 2.496 & 310 \\
\hline & 7 & 3.051 & 2.374 & 333 \\
\hline & 8 & 3.082 & 2.481 & 338 \\
\hline & 9 & 3.037 & 2.578 & 307 \\
\hline & 10 & 3.054 & 2.601 & 282 \\
\hline & 11 & 3.097 & 2.551 & 294 \\
\hline
\end{tabular}




\begin{tabular}{|c|c|c|c|c|}
\hline \multirow{5}{*}{} & 12 & 3.087 & 2.582 & 237 \\
\hline \multirow{5}{*}{2019} & 1 & 3.005 & 2.439 & 299 \\
\cline { 2 - 5 } & 2 & 2.996 & 2.465 & 241 \\
\cline { 2 - 5 } & 3 & 3.008 & 2.410 & 251 \\
\cline { 2 - 5 } & 4 & 3.009 & 2.459 & 258 \\
\cline { 2 - 5 } & 5 & 3.046 & 2.435 & 254 \\
\cline { 2 - 5 } & 6 & 2.986 & 2.548 & 227 \\
\cline { 2 - 5 } & 7 & 3.048 & 2.538 & 217 \\
\cline { 2 - 5 } & 9 & 3.018 & 2.438 & 291 \\
\cline { 2 - 5 } & 10 & 3.042 & 2.587 & 182 \\
\cline { 2 - 5 } & 11 & 3.063 & 2.531 & 177 \\
\cline { 2 - 5 } & 12 & 3.037 & 2.616 & 141 \\
\hline
\end{tabular}

Sumber : KPP Pratama Palembang Ilir Timur

Berdasarkan penyajian tabel data diatas antara jumlah Wajib Pajak lapor SPT tepat waktu dan tidak tepat waktu lapor SPT. Pelaporan SPT Masa PPN pada bulan Januari tahun 2017 sebanyak 2.925, tahun 2018 sebanyaj 3.019, dan tahun 2019 sebanyak 3.005. Jumlah WPOP lapor SPT tepat waktu pada bula Januari tahun 2017 sebanyak 2.414, tahun 2018 sebanyak 2.514, dan tahun 2019 sebanyak 2.439. Jumlah lapor SPT Masa PPN Tidak Tepat Waktu pada bulan januari tahun 2017 sebanyak 111, tahun 2018 sebanyak 365, dan tahun 2019 sebanyak 299. Dari data di atas dapat disimpulkan bahwa adanya peningkatan dan penurunan Wajib Pajak dalam Pelaporan E-SPT Masa PPN serta masih banyak WPOP yang Lapor SPT Masa PPN tidak tepat waktu hal ini belum menunjukkan kepatuhan Wajib Pajak dalam Pelaporan SPT Masa PPN dengan menggunakan E-SPT PPN pada Kantor Pelayanan Pajak Pratama Palembang Ilir Timur.

\section{B. KAJIAN TEORI}

\section{Pengertian Pajak}

Soemitro dalam Resmi (2019:01), Pajak adalah iuran rakyat kepada Negara berdasarkan undang-undang (yang dapat dipaksakan) dengan tidak mendapat jasa timbal balik (kontraprestasi) yang langsung dapat ditunjukkan dan yang digunakan untuk membayar pengeluaran umum. Definisi tersebut kemudian disempurnakan menjadi :Pajak adalah peralihan kekayaan dari pihak rakyat kepada kas Negara untuk membiayai pengeluaran rutin dan "surplus"-nya digunakan untuk public saving yang merupakan sumber utama untuk membiayai public saving.

Fungsi pajak yaitu sebagai berikut:

a. Fungsi budgetair (sumber keuangan negara)

b. Fungsi regulareng (pengatur).

Terdapat berbagai jenis pajak yang dapat dikelompokan menjadi tiga, yaitu pengelompokan menurut golongan, menurut sifat, dan menurut lembaga pemungutnya, yaitu sebagai berikut:

a. Menurut Golongan

1. Pajak Langsung

2. Pajak Tidak Langsung

b. Menurut Sifat

1. Pajak Subjektif

2. Pajak objektif

c. Menurut Lembaga Pemunggut 
1. Pajak Negara

2. Pajak Daerah

\section{Pengertian Surat Pemberitahuan Secara Elektronik (E-SPT)}

Berdasarkan Surat Edaran Direktorat Jenderal Pajak Nomor SE-03/PJ/2019 Tentang Petunjuk Tata Cara Penyampaian, Penerimaan, Dan Pengelolaan Surat Pemberitahuan, E-filling adalah cara penyampaian SPT melalui saluran tertentu yang ditetapkan Direktorat Jenderal Pajak. SPT E-filling adalah SPT dalam bentuk elektronik yang disampaikan WP melalui E-filling.

Menurut Surat Edaran Direktorat Jenderal Pajak Nomor SE-03/PJ/2019 Tentang Petunjuk Tata Cara Penyampaian, Penerimaan, Dan Pengelolaan Surat Pemberitahuan, Surat Pemberitahuan terdiri dari:

1. SPT Tahunan Pajak Penghasilan yang meliputi:
a. SPT Tahunan Pajak Penghasilan WP orang pribadi (SPT 1770, SPT 1770S, SPT 1770SS);
b. SPT Tahunan Pajak Penghasilan WP Badan (SPT 1771 dan SPT 1771\$), termasuk SPT Tahunan Pembetulan.

2. SPT Masa meliputi:

a.SPT Masa Pajak Penghasilan (SPT Masa PPh Pasal 21, SPT Masa PPh Pasal 22, SPT Masa PPh Pasal 23/26,SPT Masa PPh Pasal 25,SPT Masa PPh Pasal 15,SPT Masa PPh Pasal 4 ayat 2); dan

b. SPT Masa Pajak Pertambahan Nilai (SPT Masa PPN 1111, SPT Masa PPN 1111DM, SPT Masa PPN 1107 PUT), termasuk SPT Masa Pembetulan.

\section{Kewajiban Pengisian SPT}

Kewajiban melaporkan penghitungan dan/atau pembayaran pajak, objek pajak dan/atau bukan objek pajak, dan/atau harta dan kewajiban sesuai dengan ketentuan peraturan perundang-undangan perpajakan dalam SPT tercantum dalam pasal 3 ayat 1 UU KUP yang berbunyi sebagai berikut (Susyanti (2016:21)):

"setiap Wajib Pajak wajib mengisi SPT dengan benar, lengkap, dan jelas, dalam bahasa Indonesia dengan menggunakan huruf latin, angka Arab, satuan mata uang Rupiah, dan menandatangani serta menyampaikannya ke kantor DJP tempat Wajib Pajak terdaftar atau dikukuhkan atau tempat lain yang ditetapkan oleh Dirjen Pajak."

SPT yang telah diisi dengan benar, lengkap, dan jelas tersebut wajib disampaikan kekantor DJP tempat Wajib Pajak terdaftar atau dikukuhkan atau tempat lain yang ditetapkan oleh DJP, dan kewajiban penyampaian SPT oleh pemotong atau pemungut pajak dilakukan untuk setiap Masa Pajak.

\section{Penyampaian SPT Secara Elektronik}

Berdasarkan Surat Edaran Direktorat Jenderal Pajak Nomor SE-03/PJ/2019 Tentang Petunjuk Tata Cara Penyampaian, Penerimaan, Dan Pengelolaan Surat Pemberitahuan. Alur Penerimaan SPT e-filling yaitu:

Mengisi SPT atau membuat SPT melalui aplikasi dalam bentuk dokumen elektronik.

1.) Mengirimkan SPT dalam bentuk dokumen elektronik termasuk mengunggah dokumen lampiran dalam format PDF melalui DJP atau laman penyalur SPT Elektronik.

2.) Memperbaiki isian dalam bentuk dokumen elektronik apabila SPT tidak dapat disampaikan. 
3.) Mengisi kode verifikasi atau token sesuai dengan kode yang diperoleh WP pada email yang terdaftar pada menu profil WP.

4.) Memperoleh BPE pada email WP yang terdaftar pada menu profil WP.

5.) Proses selesai.

\section{SPT Dianggap Tidak Disampaikan}

Dalam pasal 3 ayat 7 UU KUP dalam Susyanti,(2016:22) dinyatakan bahwa, SPT dianggap tidak disampaikan apabila :

a. SPT tidak ditandatangani;

b. SPT tidak dilampiri keterangan dan/atau dokumen sesuai dengan peraturan Menkeu;

c. SPT lebih bayar disampaikan telah lewat 3 tahun sesudah berakhirnya Masa Pajak, bagian Tahun Pajak atau Tahunan Pajak, dan Wajib Pajak telah ditegur secara tertulis; atau

d. SPT disampaikan setelah Dirjen Pajak melakukan Pemeriksaan dan menerbitkan SKP.

Apabila SPT dianggap tidak disampaikan, Dirjen Pajak wajib memberitahukan kepada Wajib Pajak (Pasal 3 ayat (7a) UU KUP).SPT tersebut selanjutnya dianggap sebagai data perpajakan.

\section{Sanksi Terlambat atau Tidak Menyampaikan SPT}

Menurut Mardiasmo (2016:39), apabila Surat Pemberitahuan tidak disampaikan dalam jangka waktu yang telah ditentukan atau batas waktu perpanjangan penyampaian Surat Pemberitahuan, dikenai sanksi administrasi berupa denda sebesar:

1. Rp 500.000,00 (lima ratus ribu rupiah) untuk Surat Pemberitahuan Masa Pajak Pertambahan Nilai,

2. Rp 100.000,00 (seratus ribu rupiah) untuk Surat Pemberitahuan Masa lainnya,

3. Rp 1.000.000,00 (satu juta rupiah) untuk Surat Pemberitahuan Tahunan Pajak Penghasilan Wajib Pajak Badan,

4. Rp 100.000,00 (seratus ribu rupiah) untuk Surat Pemberitahuan Tahunan Pajak Penghasilan Wajib orang pribadi.

\section{Pengertian Kepatuhan Wajib Pajak}

Gunadi (2017:94) pengertian kepatuhan Wajib Pajak adalah "Dalam hal ini diartikan bahwa Wajib Pajak mempunyai kesediaan untuk memenuhi kewajiban perpajakannya sesuai dengan aturan yang berlaku tanpa perlu diadakan pemeriksaan, investigasi seksama, peringatan ataupun ancaman dan penerapan sanksi baik hukum maupun administrasi”.

\section{Kriteria Kepatuhan Wajib Pajak}

Berdasarkan Peraturan Menteri Keuangan Nomor: 39/PMK.03/2018 bahwa kriteria kepatuhan wajib pajak adalah:

1. Tepat waktu dalam menyampaikan SPT;

2. Tidak mempunyai tunggakan pajak untuk semua jenis pajak, kecuali telah memperoleh izin untuk mengamgsur atau menunda pembayaran pajak; 
3. Laporan Keuangan diaudit oleh Akuntan Publik atau lembaga pengawasan keuangan pemerintah dengan pendapat Wajar Tanpa Pengecualian selama 3 (tiga) tahun berturut-turut; dan

4. Tidak pernah dipidana karena melakukan tindak pidana di bidang perpajakan berdasarkan putusan pengadilan yang telah mempunyai kekuatan hukum tetap dalam jangka waktu 5 (lima) tahun terakhir.

Tepat waktu dalam menyampaikan SPT sebagaimana yang dimaksud diatas meliputi:

1. Wajib Pajak telah menyampaikan SPT Tahunan dalam 3 (tiga) tahun pajak terakhir yang wajib disampaikan sampai dengan akhir tahun sebelum penetapan Wajib Pajak Kriteria Tertentu, dengan tepat waktu.

2. Wajib Pajak telah menyampaikan SPT Masa pajak Januari dampai dengan November dalam Tahun Pajak terakhir sebelum penetapan Wajib Pajak Kriteria Tertenti, dan

3. Dalam hal terdapat keterlambatan penyampaian SPT Masa sebagaimana dimaksud dalam nomor dua diatas, keterlambatan tersebut harus memenuhi ketentuan sebagai berikut:

a) Tidak lebih dari 3 (tiga) Masa Pajak untuk setiap jenis pajak serta tidak berturut-turut, dan

b) Tidak lewat dari batas waktu penyampaian SPT Masa Pajak berikutnya.

\section{METODE PENELITIAN}

Penelitian ini dilakukan di Kantor Pelayanan Pajak Pratama Palembang Ilir Timur, adapun Jenis penelitian ini adalah penelitian kualitatif. Variabel dalam penelitian ini merupakan Tingkat Kepatuhan Wajib Pajak Pada Pelaporan E-SPT PPN. E-SPT adalah suatu cara penyampaian SPT yang dilakukan secara online yang real time melalui website Direktorat Jenderal Pajak. Kepatuhan Wajib Pajak merupakan Kesadaaran untuk memenuhi kewajibannya untuk mengisi formulir pajak dan menghitung sendiri jumlah pajak yang terutang dengan benar.

Adapun populasi dalam penelitian ini adalah jumlah SPT Masa PPN pada Kantor Pelayanan Pajak (KPP) Pratama Ilir Timur Palembang tahun 2017 sampai 2019 masa 12 bulan. Untuk Sampelnya adalah Laporan jumlah SPT Masa PPN Orang Pribadi yang melaporkan SPT secara secara tepat waktu maupun tidak tepat waktu tahun 2017 masa 12 bulan, tahun 2018 masa 12 bulan, dan tahun 2019 masa 12 bulan pada Kantor Pelayanan Pajak (KPP) Pratama Ilir Timur Palembang.Teknik Pengumpulan data yaitu menggunakan teknik dokumentasi dan studl pustaka, sedangkan teknik analisis data yaitu deskriptif komparatif.

Adapun pengukuran tingkat kepatuhan Wajib Pajak dalam penelitian ini yaitu perbandingan antara jumlah penyampaian SPT Wajib Pajak Orang Pribadi yang melaporkan SPT Tepat Waktu dan Tidak Tepat Waktu, Surat Direktorat Jenderal Pajak Nomor SE-18/PJ.22/2006 terdapat tata cara perhitungan tingkat kepatuhan Wajib Pajak sebagai berikut:

Tingkat Kepatuhan lapor SPT (\%) $=\frac{\text { Jumlah Penyampaian SPT }}{\text { Jumlah Wajib Pajak Terdaftar }} \times 100 \%$ 
Adapun pengukuran kepatuhan pajak lainnya dapat juga menggunakan rumus rasio yaitu perbandingan antara jumlah Wajip Pajak yang melaporkan SPT lapor tepat waktu dan yang Tidak Tepat Waktu lapor SPT. perhitungan rasio tepat waktu pelaporan SPT dapat dirumuskan sebagai berikut:

Tingkat Kepatuhan Waktu Lapor SPT (\%)

$$
=\frac{\text { tepat waktu }- \text { tidak tepat waktu }}{\text { jumlah WP yang Terdaftar }} \times 100 \%
$$

Adapun berikut ini Kriteria Kepatuhan Wajib Pajak berdasarkan peraturan yang ada di KPP Pratama Ilir Timur, yaitu sebagai berikut dalam Hilma Yunia (2019:31):

Tabel Kriteria Kepatuhan Wajib Pajak

\begin{tabular}{|c|c|}
\hline Rasio & Kepatuhan Wajib Pajak \\
\hline$>100$ & Sangat Patuh \\
\hline $90-100$ & Patuh \\
\hline $80-90$ & Cukup Patuh \\
\hline $60-80$ & Kurang Patuh \\
\hline$>60$ & Tidak Patuh \\
\hline
\end{tabular}

Sumber: KPP Pratama Ilir Timur Palembang 2020

\section{HASIL DAN PEMBAHASAN}

1. Hasil Penelitian

Analisis Deskriptif Komparatif Kepatuhan Wajib Pajak Orang Pribadi

Tabel Peningkatan/Penurunan Wajib Pajak Orang Pribadi Lapor SPT Di Kpp Pratama Ilir Timur 2017-2019

\begin{tabular}{|c|c|c|c|c|c|}
\hline TAHUN & BULAN & $\begin{array}{l}\text { JUMLAH } \\
\text { WPOP LAPOR } \\
\text { SPT MASA } \\
\text { PPN (a) }\end{array}$ & $\begin{array}{c}\text { JUMLAH } \\
\text { WPOP LAPOR } \\
\text { SPT } \\
\text { SEBELUMNYA } \\
\text { (b) }\end{array}$ & $\begin{array}{l}\text { PENINGKATAN/ } \\
\text { PENURUNAN } \\
\text { KEPATUHAN } \\
\text { WPOP(c=b-a) }\end{array}$ & $\begin{array}{c}\text { PERSENTASE } \\
\text { PENINGKATAN/ } \\
\text { PENURUNAN } \\
\text { KEPATUHAN } \\
\text { WPOP(c/b*100\%) }\end{array}$ \\
\hline \multirow{12}{*}{2017} & 1 & 2.925 & - & - & - \\
\hline & 2 & 2.922 & 2.925 & 3 & 0,102564 \\
\hline & 3 & 2.973 & 2.922 & -51 & $-1,74538$ \\
\hline & 4 & 2.952 & 2.973 & 21 & 0,706357 \\
\hline & 5 & 2.952 & 2.952 & - & 0 \\
\hline & 6 & 2.953 & 2.952 & -1 & $-0,03388$ \\
\hline & 7 & 2.996 & 2.953 & -43 & $-1,45615$ \\
\hline & 8 & 2.986 & 2.996 & 10 & 0,333778 \\
\hline & 9 & 2.983 & 2.986 & 3 & 0,100469 \\
\hline & 10 & 2.980 & 2.983 & 3 & 0,10057 \\
\hline & 11 & 2.994 & 2.980 & -14 & $-0,4698$ \\
\hline & 12 & 3.030 & 2.994 & -36 & $-1,2024$ \\
\hline \multirow{7}{*}{2018} & 1 & 3.019 & 3.030 & 11 & 0,363036 \\
\hline & 2 & 2.961 & 3.019 & 58 & 1,921166 \\
\hline & 3 & 2.955 & 2.961 & 6 & 0,202634 \\
\hline & 4 & 2.993 & 2.955 & -38 & $-1,28596$ \\
\hline & 5 & 3.107 & 2.993 & -114 & $-3,80889$ \\
\hline & 6 & 3.011 & 3.107 & 96 & 3,089797 \\
\hline & 7 & 3.051 & 3.011 & -40 & $-1,32846$ \\
\hline
\end{tabular}




\begin{tabular}{|c|c|c|c|c|c|}
\hline & 8 & 3.082 & 3.051 & -31 & $-1,01606$ \\
\hline & 9 & 3.037 & 3.082 & 45 & 1,460091 \\
\hline & 10 & 3.054 & 3.037 & -17 & $-0,55976$ \\
\hline & 11 & 3.097 & 3.054 & -43 & $-1,40799$ \\
\hline & 12 & 3.087 & 3.097 & 10 & 0,322893 \\
\hline \multirow{12}{*}{2019} & 1 & 3.005 & 3.087 & 82 & 2,656301 \\
\hline & 2 & 2.996 & 3.005 & 9 & 0,299501 \\
\hline & 3 & 3.008 & 2.996 & -12 & $-0,40053$ \\
\hline & 4 & 3.009 & 3.008 & -1 & $-0,03324$ \\
\hline & 5 & 3.046 & 3.009 & -37 & $-1,22964$ \\
\hline & 6 & 2.986 & 3.046 & 60 & 1,969796 \\
\hline & 7 & 3.048 & 2.986 & -62 & $-2,07636$ \\
\hline & 8 & 3.018 & 3.048 & 30 & 0,984252 \\
\hline & 9 & 3.042 & 3.018 & -24 & $-0,79523$ \\
\hline & 10 & 3.063 & 3.042 & -21 & $-0,69034$ \\
\hline & 11 & 3.037 & 3.063 & 26 & 0,848841 \\
\hline & 12 & 2.945 & 3.037 & 92 & 3,029305 \\
\hline
\end{tabular}

\section{Sumber: KPP Pratama Ilir Timur Palembang,data diolah (2020)}

Dari tabel diatas dapat dilihat peningkatan atau pun penurunan kepatuhan WPOP lapor E-SPT Masa PPN setiap bulannya dari Tahun 2017 sampai Tahun 2019 mengalamai peningkatan dan penurunan yang fluktuatif atau berubah-ubah . Dilihat Pada Tahun 2017 dapat dilihat penurunan yang terlihat paling tinggi terjadi pada bulan Maret dengan persentase $-1,74538 \%$ dan penurunan terendah terjadi pada bulan Juni dengan persentase sebesar- $0,03388 \%$, sedangkan peningkatan kepatuhan pada Tahun 2017 yang terlihat tinggi terjadi pada bulan April dengan persentase sebesar 0,706357\%, dan peningkatan terendah pada Tahun 2017 yaitu pada bulan Mei dengan persentase sebesar $0 \%$.

Pada Tahun 2018 dapat dilihat penurunan yang terlihat tinggi terjadi pada bulan Mei dengan persentase $-3,80889 \%$ dan penurunan terendah terjadi pada bulan Oktober dengan persentase sebesar $-0,55976 \%$, sedangkan peningkatan kepatuhan pada Tahun 2018 yang terlihat tinggi terjadi pada bulan Juni dengan persentase sebesar 3,089797\%, dan peningkatan terendah pada Tahun 2018 yaitu pada bulan Maret dengan persentase sebesar $0,202634 \%$.

Kemudian pada Tahun 2019 penurunan yang terlihat tinggi terjadi pada bulan Juli dengan persentase $-2,07636 \%$, dan penurunan terendah terjadi pada bulan April dengan persentase sebesar $-0,03324 \%$, sedangkan peningkatan kepatuhan pada Tahun 2019 yang terlihat tinggi terjadi pada bulan Desember dengan persentase sebesar 3,029305\%, dan peningkatan terendah pada Tahun 2019 yaitu pada bulan Februari dengan persentase sebesar 0,299501\%. 

Tabel Tingkat Kepatuhan Wajib Pajak Orang Pribadi Lapor E-SPT Masa PPn
Di KPP Pratama Palembang Ilir Timur Tahun 2017-2019

\begin{tabular}{|c|c|c|c|c|c|c|}
\hline TAHUN & BULAN & $\begin{array}{l}\text { JUMLAH } \\
\text { SPT } \\
\text { MASA } \\
\text { PPN (A) }\end{array}$ & $\begin{array}{l}\text { JUMLAH } \\
\text { WPOP } \\
\text { LAPOR } \\
\text { SPT } \\
\text { MASA } \\
\text { PPN } \\
\text { TEPAT } \\
\text { WAKTU } \\
\text { (b) }\end{array}$ & $\begin{array}{c}\text { JUMLAH } \\
\text { WPOP } \\
\text { TELAT } \\
\text { LAPOR } \\
\text { SPT } \\
\text { MASA } \\
\text { PPN (c) }\end{array}$ & $\begin{array}{c}\text { PERSENTASE } \\
\text { PENINGKATAN/ } \\
\text { PENURUNAN } \\
\text { WPOP LAPOR } \\
\text { SPT MASA } \\
\text { PPN(d=b- } \\
\text { c/a*100\%) }\end{array}$ & $\begin{array}{c}\text { TINGKAT } \\
\text { KEPATUHAN } \\
\text { WPOP LAPOR } \\
\text { SPT MASA } \\
\text { PPN }\end{array}$ \\
\hline \multirow{12}{*}{2017} & 1 & 2.925 & 2.414 & 111 & 78,73504 & KURANG PATUH \\
\hline & 2 & 2.922 & 2.471 & 171 & 78,71321 & KURANG PATUH \\
\hline & 3 & 2.973 & 2.403 & 142 & 76,05113 & KURANG PATUH \\
\hline & 4 & 2.952 & 2.401 & 132 & 76,86314 & KURANG PATUH \\
\hline & 5 & 2.952 & 2.414 & 109 & 78,08266 & KURANG PATUH \\
\hline & 6 & 2.953 & 2.515 & 113 & 81,34101 & CUKUP PATUH \\
\hline & 7 & 2.996 & 2.441 & 125 & 77,30307 & KURANG PATUH \\
\hline & 8 & 2.986 & 2.461 & 134 & 77,93034 & KURANG PATUH \\
\hline & 9 & 2.983 & 2.566 & 129 & 81,69628 & CUKUP PATUH \\
\hline & 10 & 2.980 & 2.677 & 150 & 84,79866 & CUKUP PATUH \\
\hline & 11 & 2.994 & 2.689 & 91 & 86,77355 & CUKUP PATUH \\
\hline & 12 & 3.030 & 2.614 & 80 & 83,63036 & CUKUP PATUH \\
\hline \multirow{12}{*}{2018} & 1 & 3.019 & 2.514 & 365 & 71,18251 & KURANG PATUH \\
\hline & 2 & 2.961 & 2.390 & 308 & 70,31408 & KURANG PATUH \\
\hline & 3 & 2.955 & 2.345 & 443 & 64,36548 & KURANG PATUH \\
\hline & 4 & 2.993 & 2.451 & 331 & 70,83194 & KURANG PATUH \\
\hline & 5 & 3.107 & 2.519 & 360 & 69,48825 & KURANG PATUH \\
\hline & 6 & 3.011 & 2.496 & 310 & 72,60046 & KURANG PATUH \\
\hline & 7 & 3.051 & 2.374 & 333 & 66,8961 & KURANG PATUH \\
\hline & 8 & 3.082 & 2.481 & 338 & 69,53277 & KURANG PATUH \\
\hline & 9 & 3.037 & 2.578 & 307 & 74,77774 & KURANG PATUH \\
\hline & 10 & 3.054 & 2.601 & 282 & 75,9332 & KURANG PATUH \\
\hline & 11 & 3.097 & 2.551 & 294 & 72,87698 & KURANG PATUH \\
\hline & 12 & 3.087 & 2.582 & 237 & 75,96372 & KURANG PATUH \\
\hline \multirow{12}{*}{2019} & 1 & 3.005 & 2.439 & 299 & 71,21464 & KURANG PATUH \\
\hline & 2 & 2.996 & 2.465 & 241 & 74,23231 & KURANG PATUH \\
\hline & 3 & 3.008 & 2.410 & 251 & 71,77527 & KURANG PATUH \\
\hline & 4 & 3.009 & 2.459 & 258 & 73,14722 & KURANG PATUH \\
\hline & 5 & 3.046 & 2.435 & 254 & 71,6021 & KURANG PATUH \\
\hline & 6 & 2.986 & 2.548 & 227 & 77,7294 & KURANG PATUH \\
\hline & 7 & 3.048 & 2.538 & 217 & 76,14829 & KURANG PATUH \\
\hline & 8 & 3.018 & 2.438 & 291 & 71,13983 & KURANG PATUH \\
\hline & 9 & 3.042 & 2.587 & 182 & 79,05983 & KURANG PATUH \\
\hline & 10 & 3.063 & 2.531 & 177 & 76,85276 & KURANG PATUH \\
\hline & 11 & 3.037 & 2.616 & 141 & 81,4949 & CUKUP PATUH \\
\hline & 12 & 2.945 & 2.759 & 101 & 90,25467 & CUKUP PATUH \\
\hline
\end{tabular}

\section{Sumber: KPP Pratama Ilir Timur Palembang,data diolah (2020)}

Dari tabel diatas dapat dijelaskan bahwa pada tahun 2017 sampai tahun 2019 wajip pajak orang pribadi yang menyampaikan E-SPT Masa PPN Tepat Waktu dan Tidak Tepat Waktu jumlahnya selalu berubah-ubah. Jika kita lihat Pada Tahun 2017, 
penurunan penyampaian E-SPT Masa PPN Tepat Waktu dan Tidak Tepat Waktu yang terlihat paling tinggi terjadi pada bulan Maret dengan persentase $76,05 \%$, sedangkan peningkatan Penyampaian E-SPT Masa PPN Tepat Waktu dan Tidak Tepat Waktu pada Tahun 2017 dengan jumlah terbanyak terjadi pada bulan November dengan persentase sebesar $86,77 \%$. Dilihat pada Tahun 2018, penurunan penyampaian E-SPT Masa PPN Tepat Waktu dan Tidak Tepat Waktu yang terlihat paling tinggi jumlahnya terjadi pada bulan Maret dengan persentase $64,36 \%$, sedangkan peningkatan Penyampaian E-SPT Masa PPN Tepat Waktu dan Tidak Tepat Waktu pada Tahun 2018 dengan jumlah terbanyak terjadi pada bulan Desember dengan persentase sebesar 75,96\%. Kemudian pada Tahun 2019 dapat dilihat Penurunan penyampaian E-SPT Masa PPN Tepat Waktu dan Tidak Tepat Waktu yang terlihat tinggi terjadi pada bulan Agustus dengan persentase $71,13 \%$, sedangkan peningkatan Penyampaian E-SPT Masa PPN Tepat Waktu dan Tidak Tepat Waktu pada Tahun 2019 dapat dilihat pada bulan Desember dengan persentase sebesar $90,25 \%$.

Dari tabel diatas juga dapat dilihat bahwa pada Tahun 2017 tingkat kepatuhan Wajip Pajak Orang Pribadi dominan Kriteria Kurang Patuh dengan persentase $76,05 \%$ - 86,77\%. Dapat dilihat pada tabel diatas ada tujuh bulan pada tahun 2017 dengan tingkat kepatuhan dengan Kriteria Kurang Patuh dan lima bulan dengan Kriteria tingkat kepatuhan yaitu Cukup Patuh. Sedangkan pada tahun 2018 tingkat kepatuhan Wajip Pajak Orang Pribadi mengalami penurunan dengan Kriteria kepatuhan dominan Kurang Patuh dengan persentase 64,36\% - 75,96\%.Kemudian pada tahun 2019 Kriteria tingkat kepatuhan juga Kurang Patuh, yaitu dengan persentase $90,25 \%-64,35 \%$. Namun sedikit mengalami peningkatan dengan hanya sepuluh bulan saja yang dengan Kriteria Kurang Patuh dan dua bulan dengan Kriteria cukup patuh pada tahun 2019.

\section{PEMBAHASAN}

Hasil analisis yang telah dilakukan antara Jumlah Wajib Pajak Lapor SPT Masa PPN tepat waktu dan Jumlah Wajib Pajak Lapor SPT Masa PPN tidak tepat waktu pada KPP Pratama Ilir Timur Menunjukkan bahwa tingkat kepatuhan Wajib Pajak Orang Pribadi yang menyampaikan E-SPT Masa PPN pada tahun 2017 sampai 2019 pada KPP Pratama Ilir Timur selalu mengalami penurunan. Dengan Kriteria Cukup Patuh pada tahun 2017 dan Kurang Patuh terjadi pada Tahun 2018 sampai tahun 2019. Sehingga dapat disimpulkan hasil dari penelitian Analisis Penggunaan E-SPT PPN Terhadap Kepatuhan Pelaporan SPT Oleh Wajib Pajak pada KPP Pratama Ilir Timur adalah Kurang Patuh.

Penelitian ini sejalan dengan penelitian yang dilakukan oleh Rostika Baterialni (2012) dengan hasil Hasil dari penelitian tersebut menunjukkan WP orang pribadi yang menyampaikan SPT tepat waktu setiap tahunnnya mengalami penurunan. Sedangkan WPOP lapor tidak tepat waktu setiap tahunnya masih cukup banyak. Ini menunjukkan bahwa tingkat kepatuhan WP dalam melaporkan SPT nya masih Sangat Rendah/Kurang Patuh.

Berdasarkan penjelasan diatas dapat diperoleh keterangan bahwa terdapat halhal yang menyebabkan terjadinya Naik/Turun tingkat kepatuhan WPOP dalam menyampaikan E-SPT Masa PPN pada KPP Pratama llir Timur. Faktor - faktor yang mungkin saja dapat mempengaruhi Kepatuhan Wajib Pajak Orang Pribadi dalam Menyampaikan E-SPT Masa PPN dengana Tepat Waktu dan Tidak Tepat Waktu dari sisi KPP Pratama llir Timur yaitu seperti kurangnya kesadaran Wajib Pajak dalam 
melaporkan E-SPT Masa PPN. Penyebab kurangnya kesadaran wajib pajak juga terkait karena wajib pajak tidak tahu kewajiban yang harus mereka penuhi setelah memperoleh NPWP. Selain itu, wajib pajak juga kurang mengerti arti penting pajak sehingga wajib pajak malas untuk melakukan pelaporan SPT pada Kantor Pelayanan Pajak. Kurang inisiatif dari wajib pajak juga merupakan salah satu kendala kurang patuhnya Pelaporan SPT tersebut. Salah satu usaha KPP Pratama Ilir Timur untuk meningkatkan kepatuhan wajib pajak yakni dengan mengadakan sosialisasai kepada wajib pajak, tetapi seringkali sosialisasi ini hanya dilakukan di tempat-tempat perkotaan saja. Sehingga menyebabkan wajib pajak yang bertempat tinggal di daerah pelosok atau jauuh dari kota semakin menjadi awam mengenai pentingnya mereka melakukan pelaporan SPT dengan menggunakan E-SPT. Maka kegiatan sosialisasi tersebut tidak menjadi efektif dalam hal untuk meningkatkan kepatuhan pelaporan SPT karena tidak tepat sasaran. Adapun faktor lainnya yang menjadi penyebab tidak tepat waktunya pelaporan SPT yaitu adanya gangguan jaringan komputer. Dalam pengimputan data, seringkali terjadi gangguan internet sehingga penginputan data berjalan lambat. Karena faktor tersebut Wajib Pajak tidak patuh dalam pelaporan E-SPT PPN karena tidak mendapat sosialisasi secara menyeluruh dan tepat sasaran serta gangguan jaringan.

Untuk mengatasi hal tersebut pihak KPP Pratama Ilir Timur telah berupaya melakukan peningkatan pelayanan kepatuhan wajib pajak dalam menyampaikan ESPT Masa PPN. Beberapa tindakan yang telah dilakukan antara lain:

1. Melakukan sosialisasi peraturan perpajakan kepada wajib pajak melalui media cetak maupun online membuat pajak korner dibeberapa titik, misalnya di mallmall, fasilitas publik, benner, iklan di televisi dan sebagainya.

2. Melakukan perbaikan komputerisasi dan jaringan internet. Hal ini diharapkan tidak adanya komplain atau masalah keterlambatan dan ketdak patuhan pelaporan oleh Wajib Pajak dalam Pelaporan SPT.

3. Menerbitkan surat teguran dan surat paksa. Untuk membuat Wajib Pajak menjadi patuh adanya surat teguran dan surat paksa hal ini diperlukan,diharapkan dapat meninngkatkan Pelaporan SPT oleh Wajib Pajak. Bagi Wajib Pajak yang tidak menyampaikan SPT Masa PPN nya sampai batas waktu yang telah ditentukan yaitu paling lama 20 (dua puluh hari) hari setelah akhir Masa Pajak. khusus untuk Surat Pemberitahuan Masa Pajak Pertambahan Nilai disampaikan paling lambat akhir bulan berikutnya setelah berakhirnya Masa Pajak.

\section{E. KESIMPULAN}

Berdasarkan hasil penelitian dan pembahasan mengenai Analisis Penggunaan E-SPT PPN Terhadap Kepatuhan Pelaporan SPT Oleh Wajib Pajak Pada Kantor Pelayanan Pajak Pratama Ilir Timur, dapat disimpulkan sebagai berikut:

1. Pelaporan E-SPT Masa PPN oleh Wajib Pajak pada Kantor Pelayanan Pajak Pratama Ilir Timur pada Tahun 2017 sampai dengan tahun 2019 setiap bulannya mengalami peningkatan dan penurunan. Peningkatan Pelaporan ESPT Masa PPN tertinggi terjadi pada Tahun 2018 bulan Mei dengan persentase 3,089797\%, sedangkan untuk penurunan Pelaporan E-SPT Masa PPN tertinggi terjadi pada Tahun 2018 bulan Juni -3,80889\%.

2. Kepatuhan Wajib Pajak dalam Pelaporan E-SPT Masa PPN dengan Tepat Waktu dan Tidak Tepat Waktu pada Kantor Pelayanan Pajak Pratama Ilir Timur Tahun 2017 sampai 2019 mengalami peningkatan maupun penurunan. 
Peningkatan Penyampaian E-SPT Masa PPN Tepat Waktu dan Tidak Tepat Waktu dengan nilai Persentase tertinggi dari tahun 2017 sampai tahun 2019 terjadi pada bulan Desember tahun 2019 dengan persentase 90,25\%, sedangkan untuk Penurunan Penyampaian E-SPT Masa PPN Tepat Waktu dan Tidak Tepat Waktu dengan nilai Persentase terendah terjadi pada bulan Maret Tahun 2018 dengan persentase 64,35\%.

3. Tingkat Kepatuhan Wajib Pajak Orang Pribadi yang menyampaikan E-SPT Masa PPN pada tahun 2017 sampai 2019 pada KPP Pratama Ilir Timur selalu mengalami Penurunan. Dengan kategori Cukup Patuh terjadi pada Tahun 2017dengan persentase 76,05\%-86,77\% dan dengan kategori Kurang Patuh terjadi pada Tahun 2018 dan 2019 dengan persentase 64,35\%-76,85\%. Sehingga dapat disimpulkan hasil dari penelitian Analisis Penggunaan E-SPT PPN Terhadap Kepatuhan Pelaporan SPT Oleh Wajib Pajak pada KPP Pratama llir Timur adalah Kurang Patuh dengan Persentase rata-rata 75,87\%.

\section{F. SARAN}

Berdasarkan kesimpulan, penulis memberikan saran kepada Kantor Pelayanan Pajak Pratama Palembang Ilir timur sebagai berikut:

1. Kantor Pelayanan Pajak Pratama Ilir Timur sebaiknya perlu melaksanakan penyuluhan tentang pelaporan perpajakan yang lebih efektif dan efisien untuk mensosialisasikan Surat Edaran Direktorat Jenderal Pajak Nomor SE03/PJ/2019 Tentang Petunjuk Tata Cara Penyampaian, Penerimaan, Dan Pengelolaan Surat Pemberitahuan, Surat Pemberitahuan yang selanjutnya disebut SPT kepada masyarakat agar masyarakat benar-benar mengerti, dan juga dapat meningkatkan Kesadaran Wajib Pajak dalam Pelaporan E-SPT Masa PPN. Contohnya dengan cara membuat iklan singkat di televisi mengenai tata cara penyampaian pelaporan E-SPT yang mudah di pahami oleh masyarakat, atau membuat video singkat tentang tata cara penyampaian pelaporan E-SPT di youtube, agar jika ada Wajib Pajak yang belum mengatahui tata cara penyampaian pelaporan E-SPT dapat melihatnya melalui situs youtube.

2. Kantor Pelayanan Pajak Pratama Ilir Timur sebaiknya dapat bekerjasama dengan pemerintah daerah setempat dalam rangka meningkatkan Kepatuhan Pelaporan E-SPT Masa PPN yang lebih efektif dan efisien, khususnya dalam tingkat kepatuhan serta ketepatan waktu dalam pelaporan penyampaian ESPT Masa PPN oleh Wajib Pajak.

3. Dalam upaya meningkatkan Penggunaan E-SPT PPN dalam Pelaporan SPT Kantor Pelayanan Pajak Pratama Ilir timur dapat menerapkan sanksi tegas dan berat bagi Wajib Pajak yang tidak melaporkan SPT dengan tidak tepat waktu. Kemudian Kantor Pelayanan Pajak Pratama Ilir Timur dapat juga memberikan penghargaan kepada Wajib Pajak yang patuh dalam menjalankan kewajiban perpajakannya. Hal ini dapat memberikan pengaruh baik pada Wajib Pajak lain dalam meningkatkan kesadaran masyarakat untuk menyampaikan SPT guna meningkatkan kepatuhan Wajib Pajak. 


\section{DAFTAR PUSTAKA}

Baterialni, Rostika. 2012. Analisis Kepatuhan Wajib Pajak Orang Pribadi Atas Pelaporan Surat Pemberitahuan (SPT) Tahunan Penghasilan (PPh) Pada Kantor Pelayanan Pajak Pratama Ciawi. Jurnal Ilmiah Akuntansi dan Keuangan. Vol. 14 No. 22 Juni 2012. Hal 71-84.

Gunadi.2017. Panduan Komprehensif Ketentuan Umum Perpajakan (KUP). Jakarta: Bea Media Indonesia.

Peraturan Menteri Keuangan Republik Indonesia Nomor 39/PMK.03/2018 Tentang Tata Cara Pengembalian Pendahuluan Kelebihan Pembayaran Pajak.

Mardiasmo.2016. Perpajakan Edisi Terbaru. Yogyakarta: CV ANDI.

Resmi,Siti.2019. Perpajakan. Jakarta: Salemba Empat.

Surat Edaran Direktorat Jenderal Pajak Nomor SE-03/PJ/2019 Tentang Petunjuk Tata Cara Penyampaian, Penerimaan, dan Pengeluaran Surat Pemberitahuan.

Surat Edaran Direktorat Jenderal Pajak Nomor SE-18/pj.22.2006 Tentang Tata Cara Perhitungan Tingkat Kepatuhan Wajib Pajak.

Susyanti, Jeni. 2016. Perpajakan. Jatim. Empat dua Media

Yunia,Hilma. 2019. Analisis Pengaruh Kepatuhan Wajib Pajak Orang Pribadi Terhadap Penerimaan Pajak di KPP Pratama Palembang llir Timur. Skripsi Universita PGRI Palembang. 